\title{
Paleoenvironment and speciation in the cave beetle complex Speonomus delarouzeei (Coleoptera, Bathysciinae)
}

\author{
Christian Juberthie *
}

SUMMARY

In the eastern part of the Pyrenees (France) the author describes a scenario of speciation in the cave species complex Speonomus delarouzeei (Coleoptera Bathysciinae); the speciation processes have been initiated by a breakdown of the ecological equilibrium induced during three glacialinterglacial episodes. The scenario is the following: - during the first glaciation (2.3-2.1 MY), psychrophilic populations ancestral to $S$. brucki were selected over the highest elevation of the range, by means of cold effect which produced an adaptive demographic advantage; adaptive characters of troglobitic species (K strategy) take place presumably in relation to colonization of caves and M.S.S.; - during the second glaciation (1.7-1.3 MY) and a more recent, $S$. charlottae, latter $S$. emiliae, diverged from troglobite ancestors of $S$. brucki without further adaptive characters, as result from stochastic and historical events.

M.S.S. generated during erosional period of glacial event provided ways for migration and new niches for colonization.

Bottleneck effect in size population of ancestors, founder effect, and colonization by local population which present genetic and behavioural geographical polymorphism, argue for a rapid speciation, presumably 100,000 years long and 50,000 generations in the case of $S$. emiliae.

The object of the present paper is to present up two models of microspeciation in cave-beetles related to paleoclimatic events in the temperate zone. These models arise from the results of genetical, ethological, ecophysiological, biometrical and ecologi-

* Laboratoire Souterrain du CNRS-Moulis, 09200 Saint-Girons, France. 
cal studies performed by myself and several authors (1) on the Speonomus delarouzeei complex, distributed in the eastern part of the Pyrenees. The first model involves the climatic change of the late Pliocene, during which tropical climate was replaced by temperate and mediterrean climates and is concerned with associated adaptive events. The second model arises from glacial-interglacial Pleistocene events and their impact on mountain slopes, and is mainly concerned with stochastic events without adaptive effect on beetles populations inhabiting cave and M.S.S. (Milieu souterrain superficiel). The two models habitats support the hypothesis of rapid evolution due to founder and bottleneck effects on population size.

In tropical volcanic regions, where the glaciations had no direct effect, Howarth (1980) suggests that climatic fluctuations are not essential in initiating troglobitic colonization and speciation in the Hawaian lava tube cave systems. The recent data on the Speonomus delarouzeei complex and on the paleoecology of the southern part of Europe provide a basis to reexamen and discuss the role of glaciation on speciation in cave beetles in the Pyrenean mountains located near the Mediterranean, and to compare with the scenarios of Barr (1968), Barr and Holsinger (1985), Culver $(1971,1982)$, and Peck $(1980,1981)$ for United States cave species groups.

\section{RANGE AND DISTRIBUTION OF THE SPEONOMUS DELAROUZEEI COMPLEX}

The species of the complex $S$. delarouzeei are distributed in the eastern part of the Pyrenees, in the northeast of the Catalan country, from Mont Canigou to the Rio Ter, a distance of 60 $\mathrm{km}$ from north to south, and from Girona to the Rio Llobregat, $100 \mathrm{~km}$ from east to west (Fig. 1).

The populations inhabit cave or M.S.S. habitats under different surface climates, from the Mediterranean zone (from 150 $\mathrm{m}$ to $500 \mathrm{~m}$ in elevation) to the mountain and sub-alpin zone (from $500 \mathrm{~m}$ to $2000 \mathrm{~m}$ ). The first climatic zone is characterized

(1) This paper gathers data of several authors and teams. Team of Moulis: C. Juberthie, ecology and paleoenvironment, B. Delay, electrophoresis and ecophysiology, L. Juberthie-Jupeau, reproductive isolation, J. Durand, thermobiology. Team of Rome: V. Sbordoni, M. Cobolli Sbordoni, E. De Matthaeis, electrophoresis and population genetics Team of Barcelone: of Barcelone: X. Bellès, taxonomy, O. Escola and M. Blas, taxonomy and faunistic. 


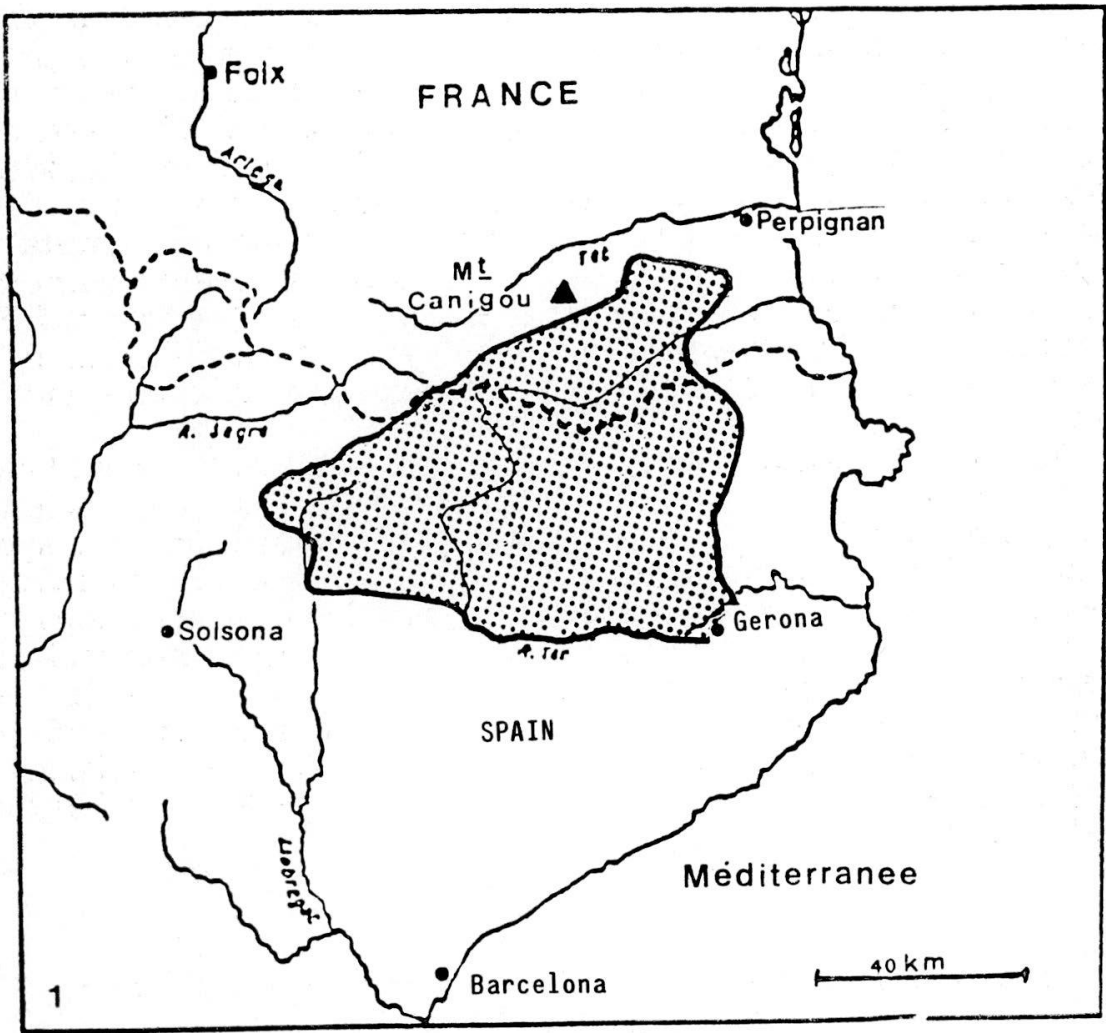

Fig. 1 - Distributional limits of the $S$. delarouzeei complex in eastern Pyrenees. Upper limits: 2,000 $\mathrm{m}$ in elevation; lower limits: $150 \mathrm{~m}$ in elevation, Southern limit: rio Ter; northern limit: Mont Canigou; eastern limit: Gerona; western limit: near rio Llobregat.

by Quercus ilex, the second by forests of Fagus sylvatica, and the third by grassland. The changes of climatic zones are rapid along the slopes of mountains.

The paleoecological evolution of climate and vegetation of this range is one of the best known (Jalut, 1977; Jalut et al., 1982; Mardones and Jalut, 1983; Suc, 1986) and the repetitive effects of Pleistocene climatic changes have been drastic.

The fact that $S$. delarouzeei s. l. inhabits M.S.S. as well as caves conduce to very accurate limits of the ranges of the different species, and offers way to the colonization (Juberthie, 1984). 


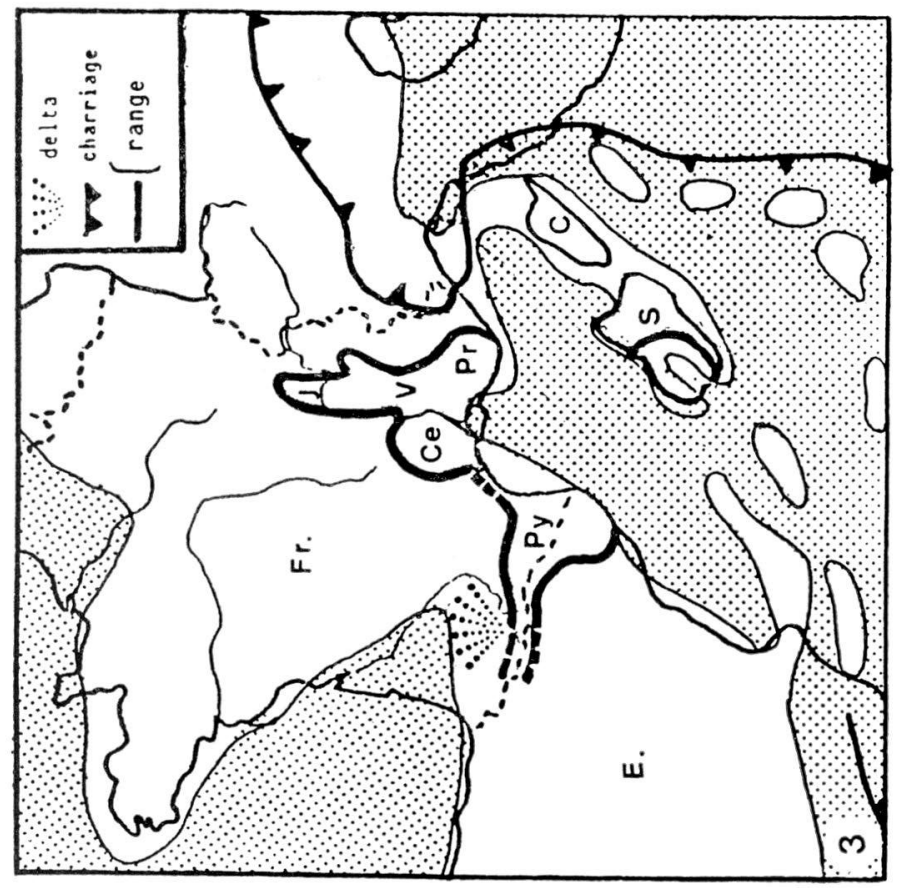

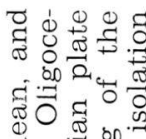

记

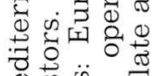

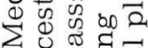

द वี द्वृत्व

जै. ज्ञ

3 어요

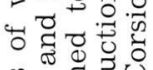

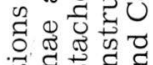

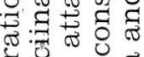

光 की

贾

ठำ

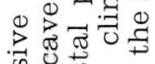

ป 0

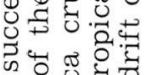

o w

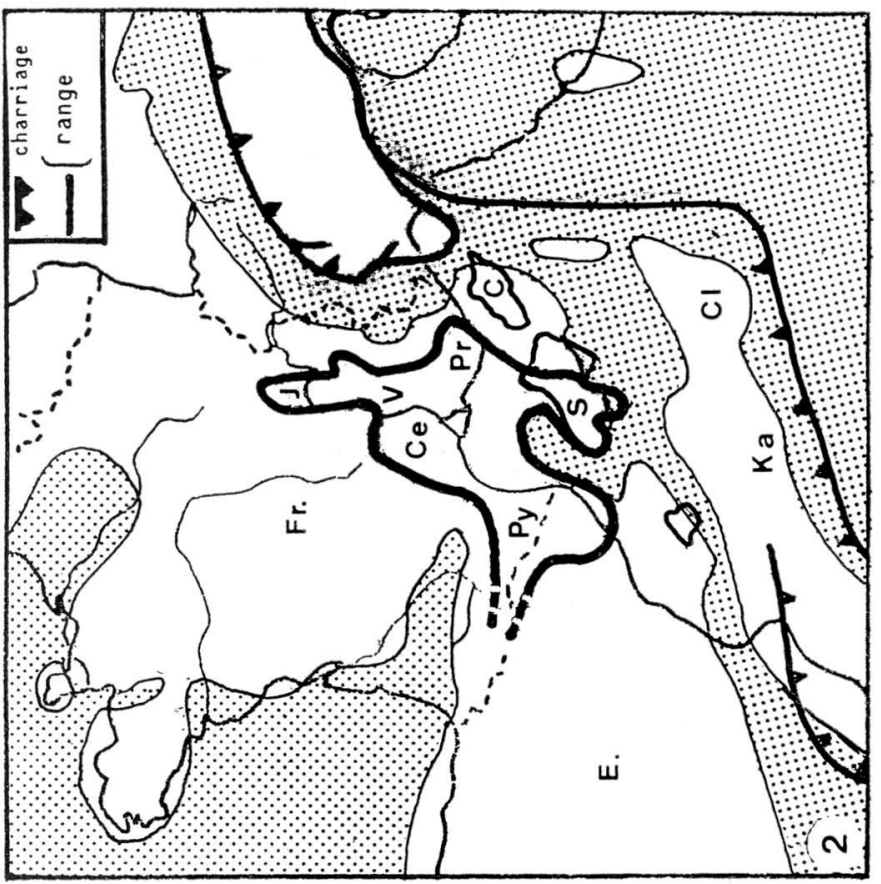

U bo 记定

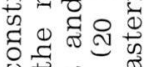
虽

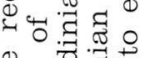

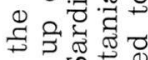
so $\omega$

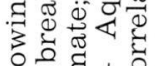

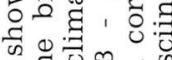
动的㐘

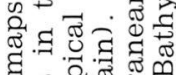
क ज त త్తై 的䒕覂焉 焉之泣 以莡

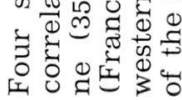
10
1
1
10
0
01 


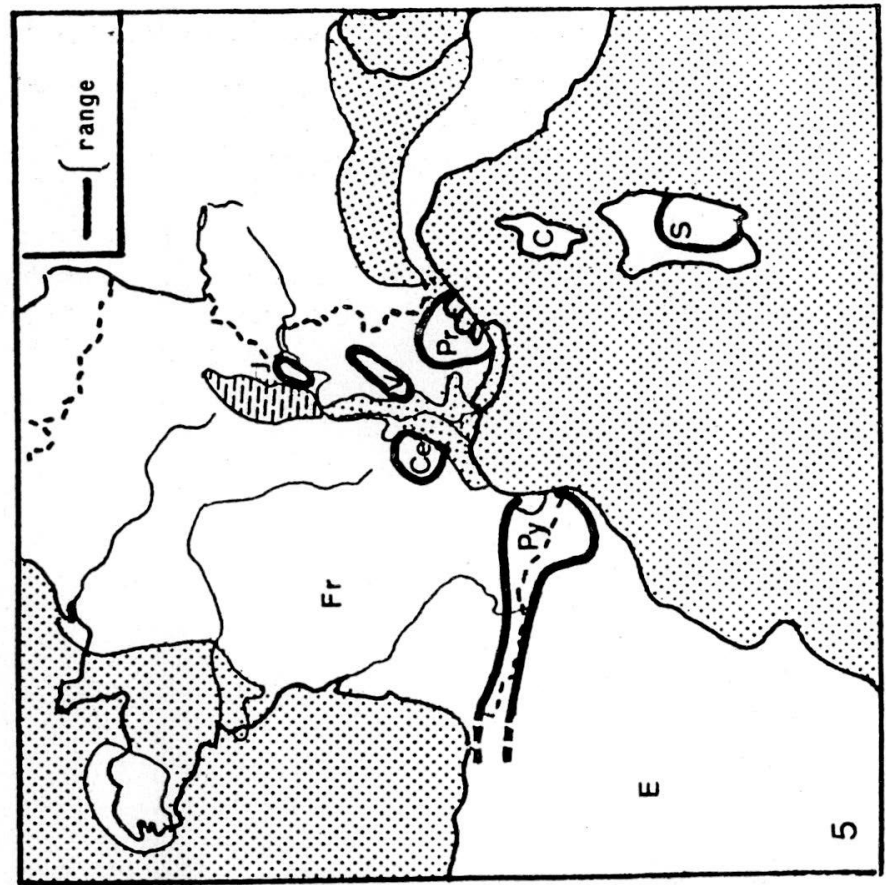

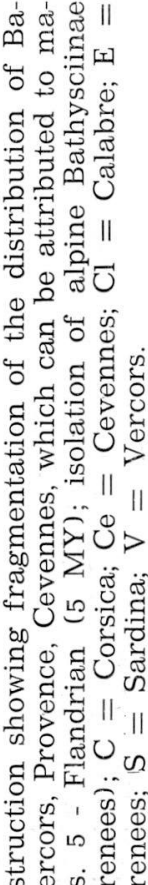

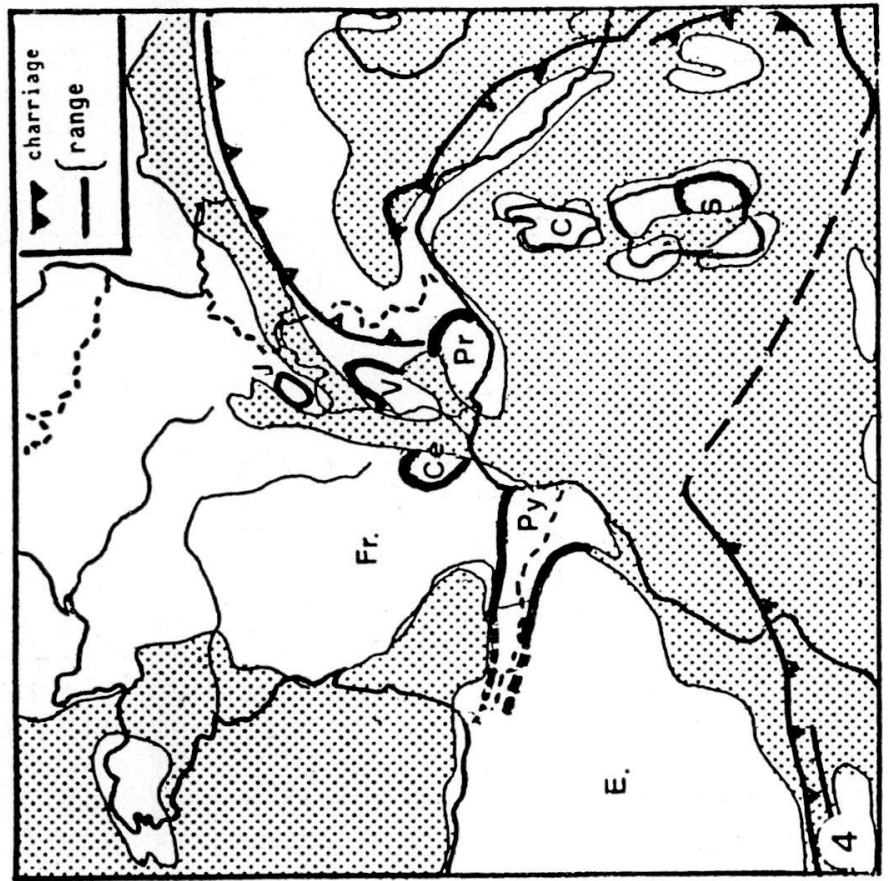

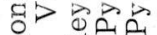

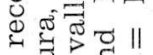

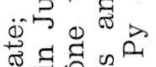

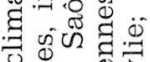
$0 \bigoplus_{0,0}^{\infty}$

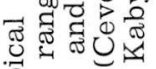
융이

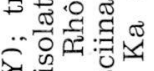
$\sum$ तี 임메 句

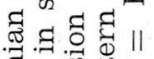
Oٓ

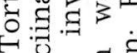

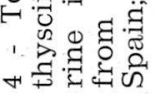




\section{PALEOBIOGEOGRAPHY; THE RANGE AND DIFFERENTIATION OF SPEONOMUS \\ AND S. DELAROUZEEI S. L. ANCESTORS DURING THE LATE TERTIARY AND QUATERNARY}

Knowledge of tectonic, paleoclimatic and geologic events is extremely valuable for understanding the ranges of species and for determining the rate of evolution in the group.

According to Jeannel (1952), the oculate or microphthalmic ancestors of Bathysciinae inhabited the soil of tropical forests but I think also limestone caves, cracks and voids of the M.S.S.; indeed, Oromi et al. (1986) discovered M.S.S. under the soil of relict tropical forest in the Canary Islands at an elevation of $1000 \mathrm{~m}$ in Tenerife, inhabited by Pterostichus which are partly pigmented oculate or microphthalmic. The range of the ancestors of Speonomus and others cave genera of Bathysciinae extended into the Jura, southern Alpes, Cevennes, eastern part of the Pyrenees and Sardinia (fig. 2).

Before $25 \mathrm{MY}$, Corsica and Sardinia and their tectonic plate was connected to the landmass that is to say to the area of present day Catalogne, Languedoc and Provence (Dercourt et al., 1985; Ricou et al., 1985). A chain of mountains has extended from the Pyrenees to Provence since the end of the Cretaceous (Bousquet and Vignard, 1985). The climate was tropical and rain forests covered the range of the ancestors of the troglobitic Bathysciinae at lower altitude. The forest was a Laurisylva, similar to the relict tropical forest in the Canary Islands (Bramvell and Bramvell, 1983) and the rain forest of the southern part of China. It was composed of Taxodiaceae (Sequoia, Cupressus). of Lauraceae, Bamboos, Juglandaceae, and also several typical mediterranean species such as Quercus ilex, Quercus coccifera. At medium elevation (about $500-600 \mathrm{~m}$ ) the rain-forest progressively changed into an association composed of Quercus, Ulmus, Acer, Gingko and Cupressus, Juniperus, Pinus and Abies.

About 25-20 MY (early Miocene), the chain of mountains between the Pyrenees and Provence were erodal and break (Golfe du Lion), the southern part of the "Massif Central " rose, the Corsica and Sardinia separated from the landmass with their tectonic plate drifting eastward, so that the occidental Mediterranean basin was opened (fig. 3). This was an early fragmentation of the range of the ancestors, so that Sardinian Bathysciinae were isolated from Pyrenean populations. They ultimately became the new genus Batinoscelis. We can estimate the time of genetic divergence between Batinoscelis Speonomus delarouzeei by means of electrophoresis; indeed 
Sbordoni (1982) gives a genetic distance (Nei) of 2.418 corresponding to approximately $25 \mathrm{MY}$. So, the times given by tectonic events and isoenzyme analysis are in concordance.

Between about $10 \mathrm{MY}$ (middle Miocene; Tortonian) and 5 MY (Plaisancian), the rotational movement of the CorsicaSardinia plate ended. The sea invaded the valleys of the Rhône and Saône; the sea transgression presented a barrier between alpin Bathysciinae and "Cevennes» Bathysciinae (fig. 4). The isolation of the ancestors of the alpin genera, Cytodromus, Royerella, Troglodromus, from Diaprysius and Maýeta in Cevennes was not later than $10 \mathrm{MY}$; it was perhaps earlier if the species were isolated on mountains by rain forest with compact soil and cracks filled at low altitude in valleys.

The isolation between the ancestors of Speonomus and Diaprysius, Mayeta could be dated from the same period (no later than $10 \mathrm{MY}$ ). However, the sea transgression between the Pyrenees and the Massif Central had not been extensive enough to isolate the two groups of Bathysciinae. The most probable scenario is an earlier isolation in M.S.S. and caves of mountains which were surrounded by rainforest at lower elevation. This hypothesis is supported by data on tropical rain forest in Africa and America, where this type of beetle loculate or microphthalmic) is absent, while it has been collected in high elevation caves of the Sierras in Central America (Barr, 1971) or in forest and glassland on the top of African volcanoes (Jeannel, 1935). The biochemical erosion and laterite which filled cracks, voids and M.S.S., particularly in nonkarstic areas covered by rainforest, can explain their absence. In fact granitic rocks (Montagne noire) and clay sediments (tertiary "molasses") lie between the present ranges of Speonomus and Diaprysius.

According to this hypothesis, the three groups of genera (Pyrenean; Cevennes; Alpin) had been isolated no later than 10 MY but presumably earlier in mountain M.S.S. and caves, perhaps at the beginning of the rise of the southern part of the Massif Central, from 10 to $20 \mathrm{MY}$ ago. Studies by means of other methods such as electrophoresis are necessary to test this scenario.

The first climatic event (3.2 MY) at the end of the tertiary, was a period of lower temperature (fig. 6). It induced changes over 200,000 years from tropical hot and wet climate to more temperate conditions.

About 2.3 MY, the main ecological event began. The first true glacial period, which extended for 200,000 years, played a major role in determining the range of Speonomus delarouzeei and by acting as a selective factor which differentiate the psychrophilic group of species from the mediterranean group. 


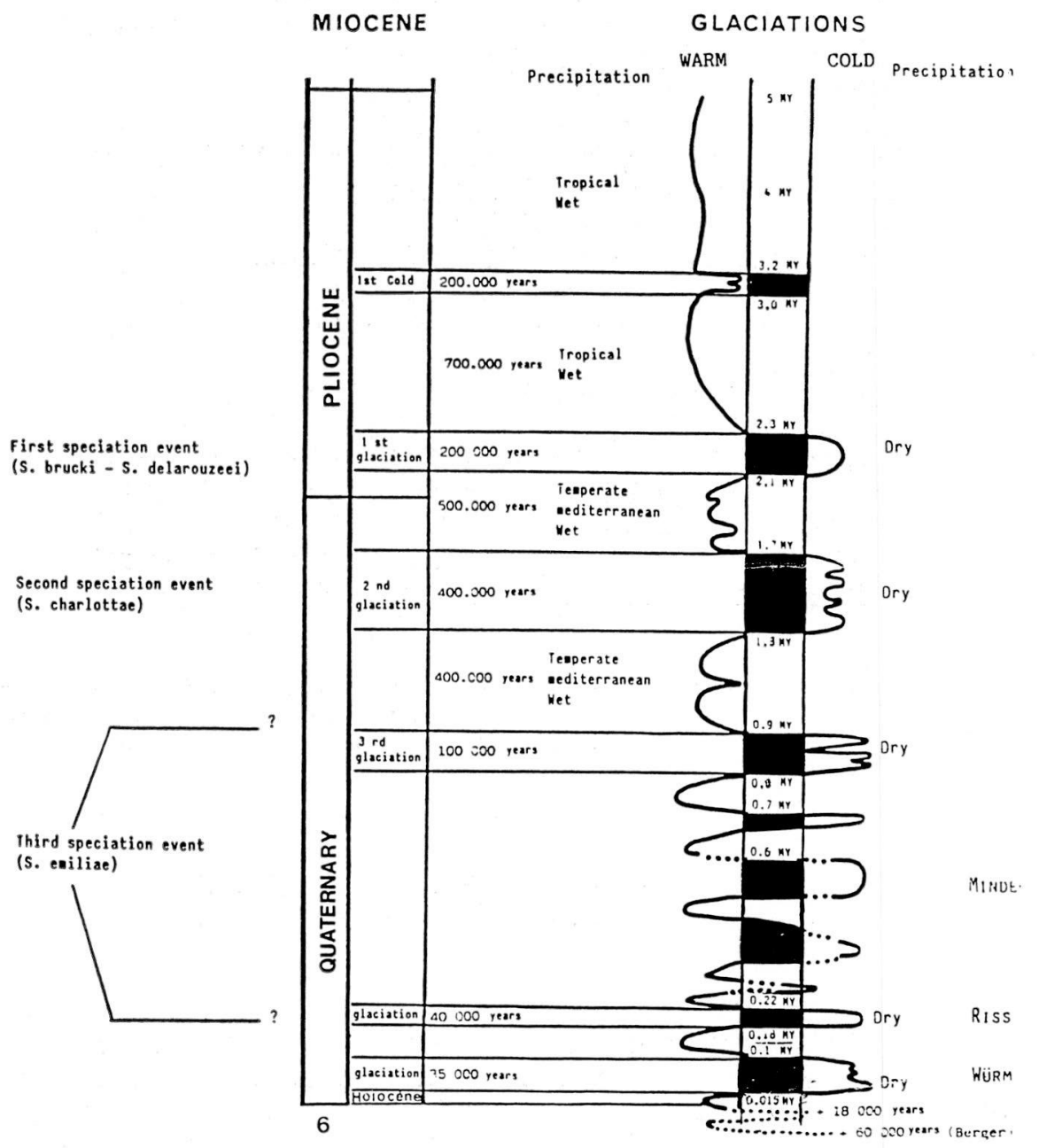

Fig. 6 - Reconstructed temperature variations during Pleistocene and Holocene showing the first glacial period and sequences of glacial and interglacial stages (from $\mathrm{H}$. Zagwijn) corresponding speciation events. 


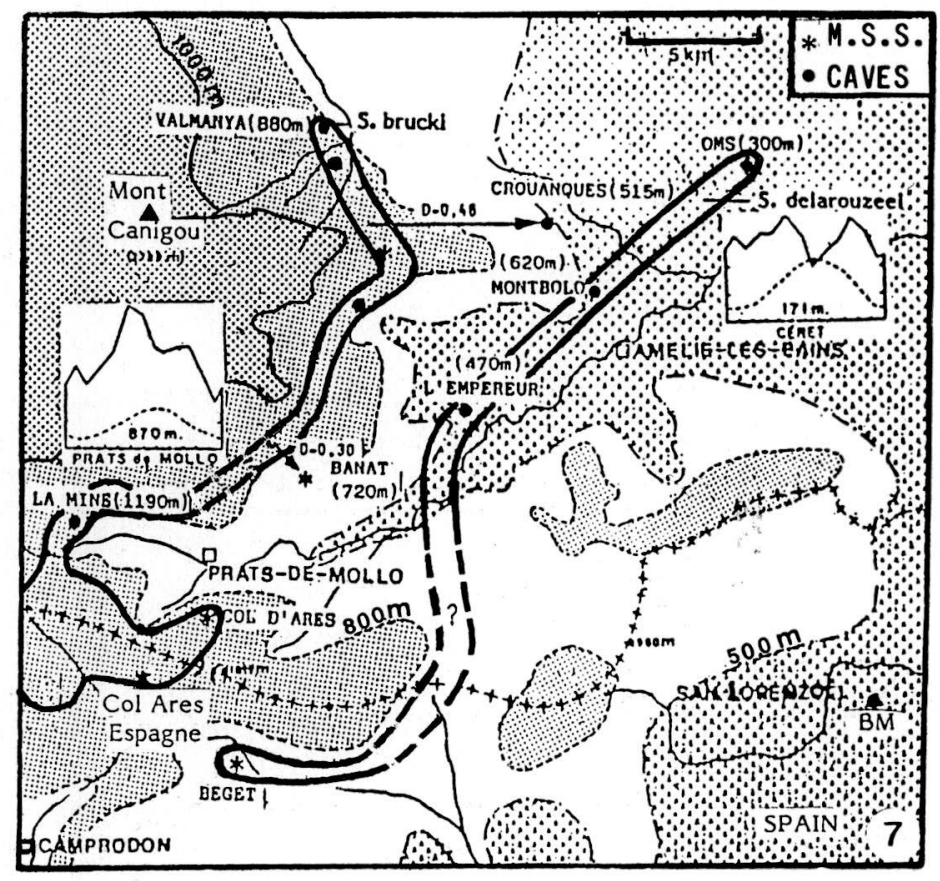

Fig. 7 - Limits of the ranges of $S$. delarouzeei and $S$. brucki; temperature and precipitation at $170 \mathrm{~m}$ in elevation (mediterranean vegetation zone), and at $870 \mathrm{~m}$ (forest mountain vegetation zone).

\section{FIRST BREAK UP OF THE COMPLEX S. DELAROUZEEI INTO TWO GROUPS}

The climate event (2.3-2.1 MY), corresponds to the first true glacial period, which established the mediterranean climate, dry and hot in summer and cold in winter, at the lower elevation of the range of the ancestors of Speonomus delarouzeei sensu lato, and established a more temperate and cold climate in mountains. The increased cold temperatures at high latitude induced dryness around the Mediterranean and the spreading of steppes with Artemisia (de Beaulieu and Suc, 1985). During the interglacial episode, at low elevation, the tropical rainforest was replaced by persistent deciduous species of which Quercus ilex was dominant. 


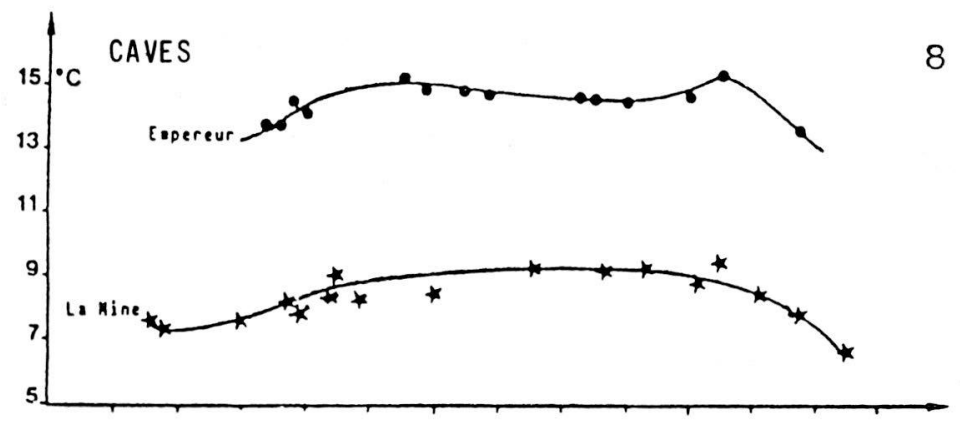

Fig. 8 - Annual temperature fluctuations in two caves: "l'Empereur" habitat of $S$. delarouzeei and "La Mine" habitat of $S$. brucki; $\mathrm{C} 1=S$. brucki; $\mathrm{C} 2=S$. delarouzeei; $\mathrm{j}$. = days; according to $\mathrm{Ju}-$ berthie et al. (1984).

Many data support the hypothesis that the first glacial period generate two basic species in the complex: Speonomus delarouzeei Fairm. sensu stricto in the mediterranean zone and Speonomus brucki Fairm. in the mountain forest zone.

The actual range of $S$. brucki (fig. 7) extends from $1000 \mathrm{~m}$ to $1500 \mathrm{~m}$ in elevation, along the slopes of the Mont Canigou, under a forest of Fagus sylvatica or at higher elevation grassland, with a maximum of rain at the late spring and more one meter annual of precipitation; the annual temperature range, for example, in the cave of "La Mine», $1190 \mathrm{~m}$ in elevation, is $7-9^{\circ} \mathrm{C}$ (fig. 8). S. delarouzeei s. stricto inhabits caves and M.S.S. in the mediterranean zone, more dry and hot in summer, with Quercus ilex vegetation; the annual temperature fluctuation is, for example, $13-15^{\circ} \mathrm{C}$ in the Cave "Resurgence de l'Empereur " (for more details see Juberthie et al., 1984).

The two species are characterized by:

1 - strongest differences in mating behaviour, $S$. brucki mates in 1 step and $S$. delarouzeei in 3 steps (fig. 10), and breeding experiments demonstrate a complete reproductive isolation (Juberthie-Jupeau and Cazals, 1984 a, b, 1985 a, b);

2 - largest genetic distance $(D=0,75)$, based on analysis of 12 loci and using Nei's method (Delay et al., 1980) (fig. 9).

There are thermobiological differences between the two main species with regard to fecundity, the speed of development of eggs and larvae. S. brucki has higher fecundity and faster development at low temperature (Delay, 1979, in press), and the upper lethal temperature is lower for $S$. brucki (Durand et al., 1984). This suggests that the cold temperatures of the 


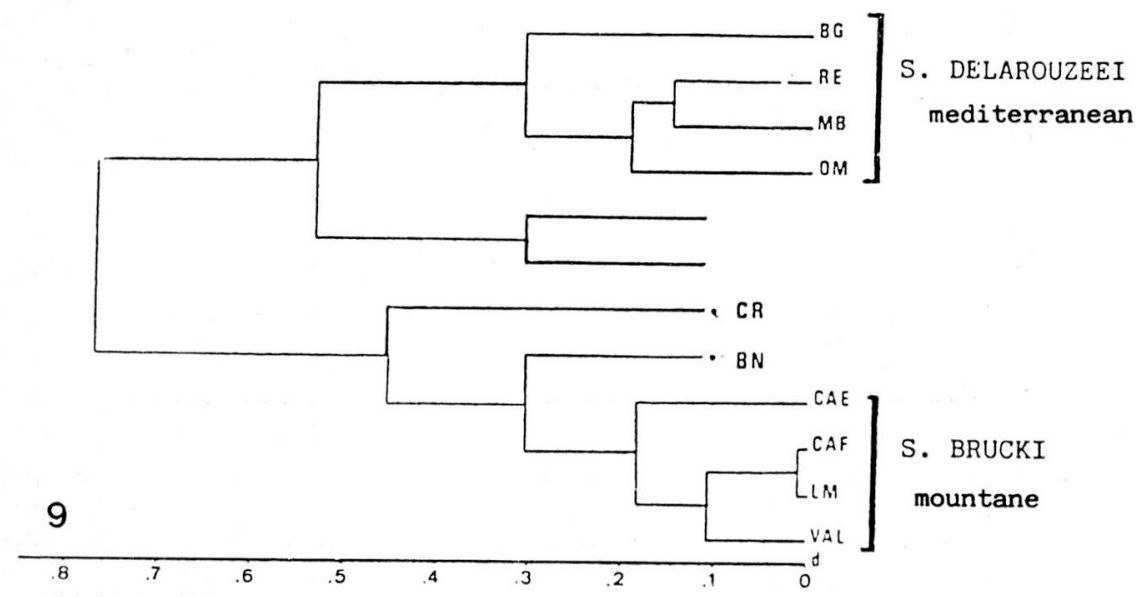

Fig. 9 - Dendrogram of genetic distances (using Nei's method), showing branching of the two main groups: S. delarouzeei (mediterranean), S. brucki (mountain), BN = M.S.S. Banat; CAE = M.S.S. Col d'Ares Spain; CAF = M.S.S. Col d'Ares France; $\mathrm{CR}=$ Crouanques Cave; $\mathrm{LM}=\mathrm{La}$ Mine; Val. = Valmanya cave; $\mathrm{BG}=$ M.S.S. Beget; $\mathrm{RE}=$ Résurgence de l'Empereur; $\mathrm{MB}=$ Montbolo cave; $\mathrm{OM}$ = Oms cave; according to Delay et al. (1980) simplified.

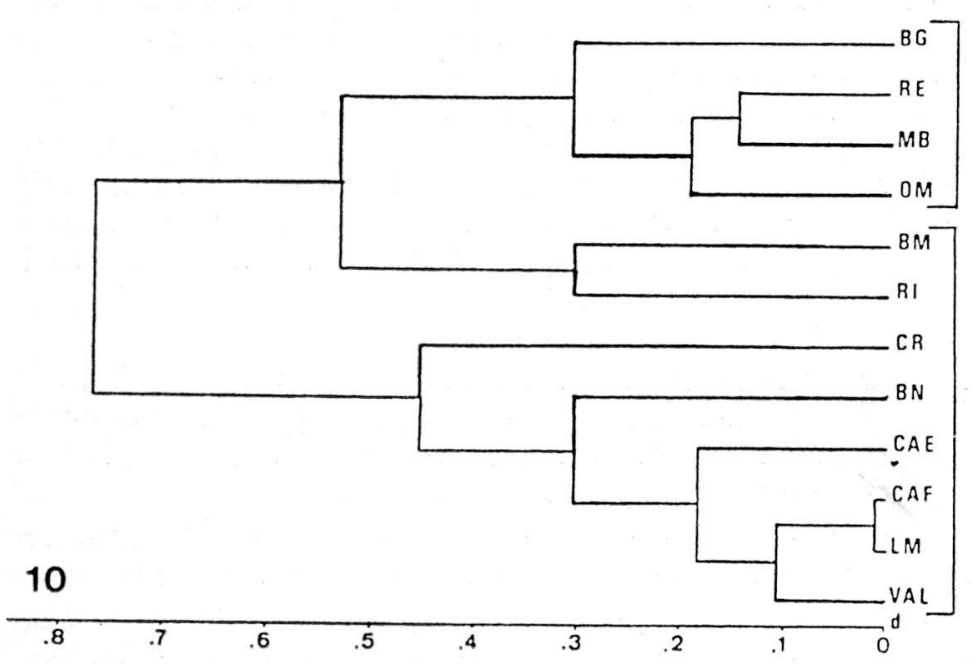

3 STEPS

S. DELAROUZEEI

1 STEP

S. BRUCKI

Fig. 10 - Dendrogram of degrees of reproductive isolation, determined by: prezygotic factors (sexual behaviour) and hybridization. $\mathrm{BM}=$ Bora Major Cave; RI = Rialb Cave; $\mathrm{CR}=$ Crouanques Cave; $\mathrm{BN}$ = M.S.S. Banat; according to Juberthie-Jupeau (in litteris). 
glacial period could have selected for psychrophilic genotypes, typical of Speonomus brucki, in the montane part of the range ( $\mathrm{on}$ the slopes of Mt Canigou) around $1000 \mathrm{~m}$ in elevation, where today the annual range of cave temperature is $8^{\circ}-10^{\circ} \mathrm{C}$. Indeed, the temperature mean has been from $5^{\circ}$ to $7^{\circ} \mathrm{C}$ lower in summer and even more in the winter during the Würm glacial period and presumably during the first glaciation, as well this agrees with the temperature range which produces a demographic advantage (cold effect) for $S$. brucki as Delay demonstrated for the eggs and larvae reared at $5^{\circ} \mathrm{C}$ (fig. 11). At warmess temperature during interglacial periods the development time difference is very slight and no advantage exists; so during these periods the temperature is a neutral factor and the selection does not occur.

In contrast, in the mediterranean part of the range where inhabited to day by $S$. delarouzeei sensu stricto, caves temperatures average $14^{\circ} \mathrm{C}$, the demographic advantage could not be expressed, because temperatures in the glacial period $\left(8^{\circ} \mathrm{C}\right.$ $9^{\circ} \mathrm{C}$ in the summer) were near to the neutral part of the developmental thermic curve (see fig. 11). However in winter the decline of temperature was probably sufficient to select some psychrophilic individuals, from no more half of eggs laid a year. This could explain the thermobiologic polymorphism observed in $S$. delarouzeei s. stricto.

The decline of temperature during the earlier climatic change (3.2 MY) was probably not enough strong to induce cold effect, and separation of the ancestral stock in two species.

The first glacial period of 200,000 years duration, was characterized by extension of steppe vegetation, gelifraction of rocks generating M.S.S. on the slopes of valleys, in both the mediterranean zone and the mountains, summer air and soil dryness in the mediterranean area, erosion of soils. Cold temperatures and changes in vegetation reduced the primary production and the level of organic matters in caves and M.S.S., according to the level of organic matter measured in layers of pollen analysis in glacial period and beginning of warming (Mardones and Jalut, 1983). This could have decreased the size of cave and M.S.S. beetle populations as well as the diversity of communities. These phenomena could had led to the disappearance of $r$ genotypes and species in M.S.S. and cave communities, and selection for $\mathrm{K}$ strategist with lower energy requirement.

The fact that $S$. brucki, S. delarouzeei and all the species of the complex show the same degree of $\mathrm{K}$ strategy, argues for a selection of genotypes adapted to low energy at the same period, presumably during the first glacial period, 2.3 - 2.1 MY, 


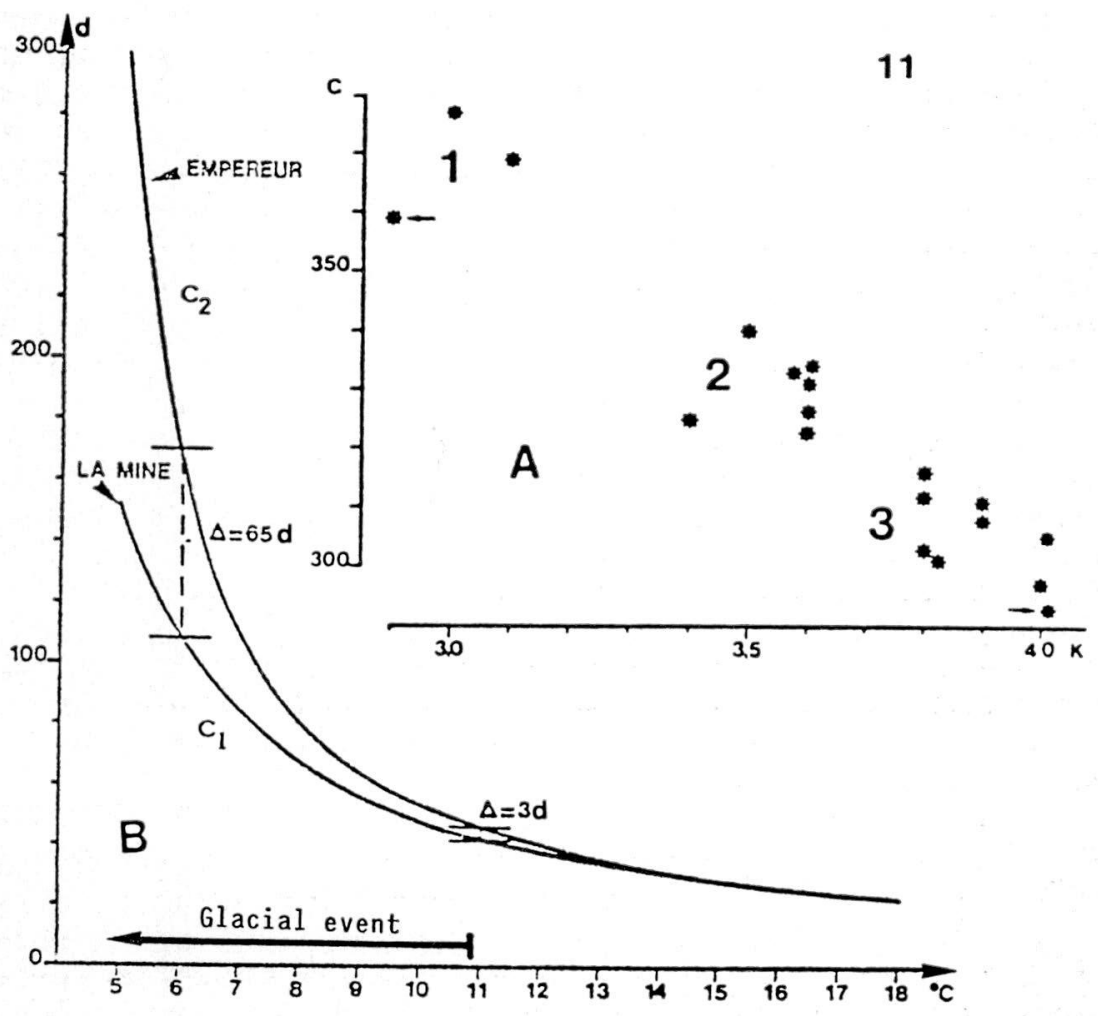

Fig. 11 - Variation of embryonic development time related to temperature. A - Embryonic time development of $S$. delarouzeei from "L'Empereur Cave". The first group (1) is more psychrophilic (low $\mathrm{K}$ and high $\mathrm{C}$ values) than the second (2) with medium $\mathrm{K}$ and $C$ values and the third (3) with high $K$ values. The value of $K$ indicates the position of the function $D=F(T)$ on the scale of temperatures (from Delay, in press). B - Speed of development of eggs of $S$. brucki (C1) and S. delarouzeei (C2) sensu stricto related to temperature. Note: The presence of a neutral temperature zone, from $18{ }^{\circ} \mathrm{C}$ to $10-9 \mathrm{oC}^{\circ}$, in which the speed of embryonic development of the two species is similar, and a range of low temperatures where a "cold effect" occurs which induces differences in speed of development with a maximum around 5 ${ }^{\circ C}$; at this temperature, the development of $S$. brucki is twice as rapid (150 days) as that of $S$. delarouzeei (300 days); from Delay (1979). 
and related to the colonization of M.S.S. and caves. This demographic pattern, typical of other cave beetles, probably has been selected very early in the cave evolution.

The strong correlation between allozymic and behavioural cendrograms suggests that the reproductive isolation and the selection of psychrophilic populations of $S$. brucki have occurred simultaneously.

Hybridization between the two sibling species may also have been suppressed by male-female incompatibility. $\sigma^{\text {t }}$ try to mate often and randomly with $q$ of their species or of other species of the complex. Male $S$. delarouzeei from cave at $13-15^{\circ} \mathrm{C}$ tend to mate with $q$ of $S$. brucki from cave at $8{ }^{\circ} \mathrm{C}$. Mating attempts result in death of the females of $S$. brucki (JuberthieJupeau, in litteris). This could contribute to the separation of the ranges of the two species.

\section{LATTER EPISODES. SPECIATION IN RELATION TO GLACIAL-INTERGLACIAL PLEISTOCENE EVENT WITHIN THE PSYCHROPHILIC AND TROGLOBITIC GROUP S. BRUCKI S.L.}

Each glacial episode displaced the forest belt several hundred meters downward in elevation, replaced forests with steppe vegetation due to the cold and dry climate, and was a period of erosion which generated cracks, voids and M.S.S. and provoked a sink phase in caves (fig. 12). Each interglacial period is characterized by warming climate, extension of forests and forest belts, and dominance of biochemical erosion which fills cracks and voids and producing barriers to gene flow.

The three sibling species, Speonomus brucki, S. emiliae n. sp. (in litteris), S. charlottae n. sp. (in litteris) have similar mating patterns (one step; fig. 10), genetic distances (Nei) between them brucki - emiliae $\mathrm{D}=0.30$, brucki - charlottae $\mathrm{D}=$ 0.46 (fig. 9) (Cobolli Sbordoni et al., 1983); breeding experiments indicate that they represent true species (Juberthie-Jupeau and Cazals, $1985 \mathrm{a}, \mathrm{b})$. This speciation within the complex occurs over a narrow elevational range from 1500 to $500 \mathrm{~m}$ on the slope of Mont Canigou. These speciation events correspond with two more recent paleoclimatic glacial-interglacial episodes.

The immediate ancestors of Speonomus emiliae, an M.S.S.dweller in Banat at $720 \mathrm{~m}$ in elevation, were probably ancestral populations of troglobitic Speonomus brucki that were com- 


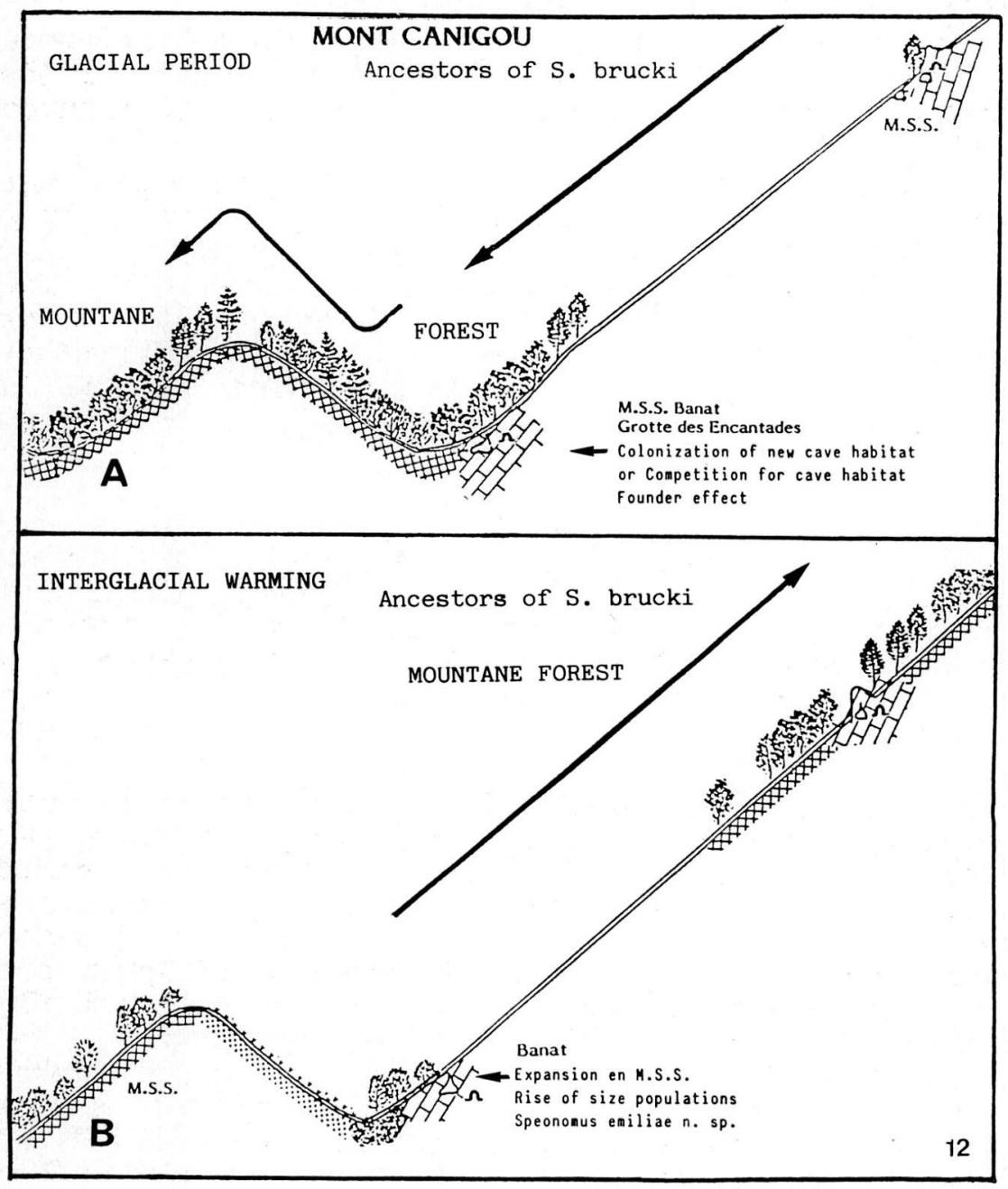

Fig. 12 - Hypothesized colonization-isolation events during a glacial-interglacial period giving rise to the $S$. emiliae. A. - Glacial period. Migration to lower elevation of the forest belt by the ancestors of $S$. emiliae through cracks and micro-voids of the M.S.S.; colonization of a newly generated M.S.S. in Banat. B. - Interglacial warming. Forest belt migrated to upper elevation; isolation and speciation of Speonomus in M.S.S. Banat. 
pressed downward altitudinally with the forest belt during a glacial period, through the cracks and voids in the M.S.S. They invaded a newly generated and well developed zone of M.S.S. in Banat (fig. 12).

During the beginning of interglacial warming, the mountain forest belt extended up, and the rapid filling of cracks and micro-voids by pedogenesis (geomorphological barriers), isolated a population in empty spaces of the large Banat M.S.S.

Peck (1980) has proposed a similar scenario, with M.S.S. unknown at this time, for the isolation of the arthropod species in Grand Canyon caves and (1981) for Ptomaphagus hirtus species group of the southeastern United States.

\section{TIME AND RATE OF SPECIATION}

Estimates of divergence times for the speciation events, using Nei's method and electrophoretic data, are 4 MY, 2.5 MY and 1.5 MY for the three events described above. The arguments presented above support more recent divergence times and, therefore, more rapid speciation. For example, the estimate of time since divergence for the two closely species, $S$. brucki and $S$. emiliae, based on Nei's distance is $1.5 \mathrm{MY}$, that correspond to the second Pleistocene glaciation (fig. 6). This estimate is undoubtedly too old, because a population of $S$. charlottae, from Crouanques cave, as a higher Nei's distance ( $D=0,46$; fig. 9) indicating that it diverged even earlier from the same ancestors.

So, a reasonable scenario is the following:

- First glaciation, 2.3 - 2.1 MY. Divergence of S. brucki and $S$. delarouzeei sensu stricto; psychrophilic populations ancestral to $S$. brucki were selected over the highest elevation of the area, due to the presence of cold climate (cold effect); adaptive characters of troglobitic species ( $\mathrm{K}$ strategy) take place;

- Second glaciation, 1.7 - 1.3 MY. S. charlottae diverged from troglobitic ancestors of $S$. brucki, on the eastern slope of Mont Canigou, due to isolation and divergence rather than an adaptative shift;

- Third glaciation, $0.9-0.8 \mathrm{MY}$ or more recent glaciations. S. emiliae arosed from troglobitic ancestors of $S$. brucki, on the southern slope of Mont Canigou, through a process of colonization - isolation in lower altitude caves or M.S.S. peripheral to the ancestral population.

The last two speciation events ( $S$. charlottae, $S$. emiliae) presumably were not related to cave adaptation because these 
new cave species have risen from cave limited ancestral population. This provides an historical and stochastic aspect to the speciation process, as Stanley (1975) has argued for other animals.

In the Mediterranean part of the range, during the second glaciation, the southern populations in Bora Major cave $(S$. gimjuani) and Rialb cave (S. catalonicus) diverged from ancestors of $S$. delarouzeei sensu stricto, that to day inhabit caves in Vallespir Valley (Résurgence de l'Empereur, Montbolo, Oms) and Bebet M.S.S. in Spain.

Several factors provide evidence for a rapid speciation:

- a bottleneck in size population of the ancestors due to the decrease of the primary production and the amount of organic resource in cave habitat, induced by the onset of the glacial climate;

- a founder effect (Templeton, 1980) related to the colonization of caves and newly-generated M.S.S., at lower elevation and in peripheral zones, by populations which possessed only a portion of the genetic variability of the parent population.

- a colonization by local elements of a general population characterized by geoghaphical, genetic and behavioural polymorphisms, related to habitat heterogeneity characterized by limestones intercalated between schistous or compact rocks.

The speciation event occurred during a breakdown of the ecological equilibrium related to the instable climates of the glacial and the beginning of the interglacial period; the break down of the ecological equilibrium occurred several times within the range of the complex, but produced new species only three times, according to the present data.

In the case of $S$. emiliae, the third and later glaciation were 100,000 years long. With a life-cycle of one year at $11^{\circ} \mathrm{C}$ and two years at $6{ }^{\circ} \mathrm{C}$, the species diverged from ancestors of $S$. brucki in no more than 50,000 generations. In the case of $S$. charlottae, the second glacial period was 400,000 years long corresponding to 200,000 generations.

Taxonomy. Morphological characters of the aedeagus (internal sac), distinguish the four species which have close morphological similarity and slight differences (Belles, 1984). The effectiveness of these internal morphological characters is supported by the great genetic distance between species and by the ethological distance as determined by breeding experiments performed by Juberthie-Jupeau et al. (1985b, 1988). In several complexes of troglobitic species of Bathysciinae and Trechinae morphological differences are very slight. Thus, a need arises to use additional biological characteristics (e. g., behavioural and isoenzymatic data) to infer systematic relationships. 


\section{CONCLUSIONS}

In the eastern part of the Pyrenees in the range of the species complex $S$. delarouzeei, the speciation process appears to have been initiated by a breakdown of the ecological equilibrium, induced by glacial episodes. This process of microspeciation occurred three times during the Quaternary, producing neoendemic cave Bathysciinae.

Two types of speciation occurred successively in the complex.

- The earlier episode presumably related to colonization of the underground habitat, involved an adaptive shift during the first glaciation which produced a cave species with an adaptive demographic advantage under conditions of cold temperature and energy availability;

- The latter episodes arose from stochastic events related to glacial-interglacial episodes producing species which diverged from the previous troglobitic ancestors without further adaptive changes.

Fracturing of rocks and development of M.S.S. during the erosional period of a glacial event, provided ways for migration and colonization of caves and made available a new niche in the newly generated M.S.S.

At low elevation (southern mediterranean part of the range of the complex) the preliminary studies supported hypothesis that species which diverged from ancestors of $S$. delarouzeei s. stricto had been isolated by compact zones generated by biochemical erosion which filled cracks and M.S.S. in the interglacial period. The result is a patchy habitat with geomorphological barriers to gene flow.

\section{ACKNOWLEDGEMENTS}

The author would like to thank Thomas Kane for his attentive linguistic corrections and Gisele Ruffat for technical help.

\section{REFERENCES}

BARR, T. C. Jr. 1968. Cave ecology and evolution of troglobites. Evolutionary Biology 2: 35-102.

BARR, T. C. Jr. 1971. A new species of Mexaphaenops from Tamaulipas, Mexico (Coleoptera, Carabidae). Bull. Assoc. mex. cave stud. 4: 113-116.

BARR, T.C. Jr. and J. HOLSINGER. 1985. Speciation in cave faunas. Ann. Rev. Ecol. Syst. 16: 313-337. 
BELLÉS, X. 1984. Estudi de l'armadura genital en les poblaciones de Speonomus (Parvospeonomus) delarouzeei, s.l. $i$ S. (P.) villarubiasi Zariquiey (Col. Catopidae, Bathysciinae) que conviuen a la Cova del Far (Susqueda, La Seleva) - Exploracions 8: 7-13.

BOUSQUET, J. C. and G. VIGNARD. 1985. Découverte géologique du Languedoc méditérranéen, $96 \mathrm{pp}$, ed. BRGM, Orléans.

BEAULIEU de, J. L., J. P. SUC. 1985. Les pollens et l'histoire de la Végétation. In: Les Climats de la Préhistoire. Hist. et Archéol. 93: 66-73.

BRAMVELL, D. and Z. BRAMVELL. 1983. Flores silvestres de la Islas Canarias. 2e éd., Rueda Ed., Madrid, $284 \mathrm{pp}$.

CARSON, H. L. and A. T. OHTA. 1981. Origin of the genetic basis of colonizing hability, p. 365-370. In: Evolution To Day, Proc. II int. Congress Syst. Evol. biology.

COBOLLI SBORDONI, M., B. DELAY, E. DE MATTHAEIS and V. SBORDONI. 1983. Divergenza genetica e barriere al flusso genico tra popolazioni cavernicole di Speonomus delarouzeei (Coleoptera, Catopidae). Atti XII Congr. Naz. Ital. Entomol., Roma, 1980, 2: 247-252.

CULVER, D. 1971. Caves as Archipelagoes. NSS Bull. 33 (2): 97-98.

CULVER, D. 1982. Cave life. Evolution and Ecology. Harvard Univ. Press, $189 \mathrm{pp}$.

DELAY, B. 1979. Variation en fonction de l'altitude des paramètres thermobiologiques du développement chez un Coléoptère Bathysciinae hypogé, Speonomus delarouzeei. Bull. Soc. Ecophysiol. 4 (1): 73-76.

DELAY, B. 1988. The cold effect a likely process of speciation. The case of subterranean beetles. Genetic, selection (in press).

DELAY, B., V. SBORDONI, M. COBOLLI SBORDONI and E. DE MATTHAEIS. 1980. Divergences génétiques entre les populations de Speonomus delarouzeei du Massif du Canigou (Coléoptères Bathysciinae). Mém. Biospéol. 7: 235-247.

DERCOURT, J., L. P. ZONENSHAIN, L. E. RICOU, V. G. KAZMIN, X. LE PICHON, A. L. KNIPPER, C. GRANDJACQUET, I. M. SBORSHCHIKOV, J. BOULIN, O. SOROKHTIN, J. GEYSSANT, C. LEPEVRIER, B. BIJU-DUVAL, J. C. SIBUET, L. A. SAVOSTIN, M. WESTPHAL and J. P. LAUER. 1985. Présentation de 9 cartes paléogéographiques au $1 / 20.000 .000$ e s'étendant de l'Atlantique au Pamir pour la période du Lias à l'Actuel. In: Paléobiogéographie de la Téthys. Bull. Soc. Géol. Fr. (8) 1 (5): 637-652.

DURAND, J., L. JUBERTHIE-JUPEAU and J. DUPUY. 1984. Différences de résistance aux températures supra-optimales dans plusieurs populations de Coléoptères Bathysciinae. Mém. Biospéol. 11: 173-177.

HOWARTH, F. 1980. The zoogeography of specialized cave animals: A bioclimatic model. Evolution 34: 394-406.

HOWARTH, F. 1981. Non-relictual terrestrial fauna troglobites in the tropical Hawaiian caves. Proc. 8th Intern. Congr. Speleol. 2: 539-541.

HOWARTH, F. 1987. The evolution of non-relictual tropical troglobites. Int. J. Speleol. 16 (1-2): 1-16.

JALUT, G. 1977. Végétation et climat des Pyrénées méditerranéennes depuis quinze mille ans. Thèse Univ. Toulouse, $141 \mathrm{pp}, 16$ fig. 16 diag.

JALUT, G., G. DELIBRIAS, J. DAGNAC, M. MARDONES, M. BOUHOURS 1982. A paleoecological approach to the last 21000 years in the Pyrenees: the peat bog of Freychinède (alt. $1350 \mathrm{~m}$, Ariège, south France). Paleogeogr., Paleoecol. 40: 321-359.

JEANNEL, R. 1935. Coleoptera. I. Carabidae: Trechinae et Perigoninae. Mission scientifique de l'Omo. Mém. Mus. nat. Hist. nat. (2) 2: 23-75.

JEANNEL, R. 1952. L'évolution souterraine dans la région méditerranéenne et sur les montagnes du Kivu. Notes Biospéol. 7: 7-13.

JEANNEL, R. 1965. La genèse du peuplement des milieux souterrains. Rev. Ecol. Biol. Sol. 2 (1): 1-22. 
JUBERTHIE, C. 1984. La colonisation du milieu souterrain; théories et modèles, relations avec la spéciation et l'évolution souterraine. Mém. Biospéol. 11: 65-102.

JUBERTHIE, C., B. DELAY, L. JUBERTHIE-JUPEAU, J. DURAND, O. ESCOLA, X. BELLES and M. BLAS. 1984. Etude du complexe Speonomus delaurozeei. Mém. Biospéol. 11: 141-164.

JUBERTHIE-JUPEAU, L. 1988. Mating behaviour and barriers to hybridization in the caves beetles of the Speonomus delarouzeei complex (Coleoptera, Catopidae, Bathysciinae). Int. J. Speleol. 17 (1-2): 51-63.

JUBERTHIE-JUPEAU, L. and M. CAZALS. 1984 a. Accouplement et comportement sexuel chez un Bathysciinae souterrain Speonomus delarouzeei Fairm. Behavioural Processes 9: 147-155.

JUBERTHIE-JUPEAU, L. and M. CAZALS. 1984 b. Modalités de l'accouplement dans différentes populations du complexe "Speonomus delarouzeei" Coléoptères Bathysciinae souterrains. Mém. Biospéol. 11: 165-172.

JUBERTHIE-JUPEAU, L. and M. CAZALS. 1985 a. Différences éthologiques dans l'accouplement de quatre populations de Coléoptères Catopidae Speonomus delarouzeei Fairm. en relation avec la spéciation. C. R. Acad. Sc. 301 (3) 8: 393-396.

JUBERTHIE-JUPEAU, L. and M. CAZALS. 1985 b. Isolement reproducteur entre deux populations ayant valeur d'espèces dans le complexe Speonomus delarouzeei, Coléoptères souterrains. C. R. Acad. Sc. 301 (3) 8: 393-396.

MARDONES, M. and G. JALUT. 1983. La tourbière de Biscaye al. $409 \mathrm{~m}$ (Hautes-Pyrénées): approche paléoécologique des 45000 dernières années. Pollen et Spores 15: 163-212.

OROMI, P., A. L. MEDINA, M. L. TEJEDOR. 1986. On the existence of a superficial underground compartment in the Canary islands. Com. 9e Congr. Intern. Espeleol., Barcelone 2: 147-151.

PECK, S. B. 1980. Climatic change and the evolution of cave invertebrates in the Grand Canyon, Arizona. NSS Bull. 42: 53-60.

PECK, S. B. 1981. Evolution of the cave Cholevinae in North America (Coleoptera Leiodidae). Proc. 8th Int. Congr. Speleol., Bowling green, Kentucky 2: 503-505.

RICOU, L. E., L. P. ZONENSHAIN, J. DERCOURT, V. G. KAZMIN, X. LE PICHON, A. L. KNIPPER, C. GRANDJACQUET, I. M. SBORSHCHIKOV, J. GEYSSANT,, C. LEPVRIER, D. M. PECHERSKY, J. BOULIN, J. C. SIBUET, L. A. SAVOSTIN, O. SOROKHTIN, M. WESTPHAL, M. L. BAZHENOV, J. P. LAUER and B. BIJU-DUVAL. 1985. Méthodes pour l'établissement de neuf cartes paléogéographiques de l'Atlantique au Pamir depuis le Lias. In: Paléobiogéographie de la Téthys. Bull. Soc. Géol. Fr. (8) 1 (5): 625-635.

SBORDONI, V. 1982. Advances in Speciation of Cave Animals, p. 219-240. In C. Barigozzi (ed.), Mechanisms of Speciation. Alan R. Liss, Inc,, New York.

STANLEY, St. M. 1975. A theory of Evolution above the species level. Proc. nat. Acad. Sci. U.S.A. 72 (2): 646-650.

SUC, J. P. 1986. Le climat méditerranéen: une particularité de toujours? La recherche 16 (162): 87-89.

TEMPLETON, A. R. 1980. The theory of speciation via the founder principle. Genetics 94: 1011-1038. 